\title{
Éric Mélac, L'évidentialité en anglais : approche contrastive à partir d'un corpus anglais-tibétain
}

\section{(2) OpenEdition \\ 12 Journals}

Édition électronique

URL : https://journals.openedition.org/emscat/2717

DOI : $10.4000 /$ emscat.2717

ISSN : 2101-0013

Éditeur

Centre d'Etudes Mongoles \& Sibériennes / École Pratique des Hautes Études

Référence électronique

"Éric Mélac, L'évidentialité en anglais : approche contrastive à partir d'un corpus anglais-tibétain », Études mongoles et sibériennes, centrasiatiques et tibétaines [En ligne], 46 | 2015, mis en ligne le 10 septembre 2015, consulté le 13 juillet 2021. URL : http://journals.openedition.org/emscat/2717 ; DOI : https://doi.org/10.4000/emscat.2717

Ce document a été généré automatiquement le 13 juillet 2021.

(c) Tous droits réservés 


\section{Éric Mélac, L'évidentialité en anglais : approche contrastive à partir d'un corpus anglais-tibétain}

\section{RÉFÉRENCE}

Thèse de doctorat en linguistique anglaise soutenue à l'Université Sorbonne Nouvelle Paris 3, le 12 décembre 2014 (520 p. + 17 p. d'annexes). Membres du jury : A. Celle, E. Corre (directeur), Ph. Miller (rapporteur), J. Nuyts, E. Sweetser (rapporteur), N. Tournadre (codirecteur), D. Ziegeler

\section{L'évidentialité en anglais : approche contrastive à partir d'un corpus anglais-tibétain}

1 L'objet de cette thèse est de fournir une description détaillée de l'évidentialité en anglais et en tibétain. L'évidentialité y est définie comme l'expression linguistique du mode d'accès à l'information énoncée. Cette étude se fonde principalement sur trois corpus spécialisés en anglais et tibétain recueillis aux universités de Lhassa et de Cambridge (TSC et CSC/LAC, 2010-2012, 10 h.). Les méthodes employées pour la constitution de ces corpus visaient à éliciter un grand nombre de formes évidentielles en posant des questions qui ont trait à différents modes d'accès à l'information, et en adoptant une méthodologie identique en anglais et en tibétain afin d'obtenir des données qualitatives et quantitatives comparables.

2 Le tibétain possède un système évidentiel complexe et grammaticalisé dont la description peut fournir une grille d'analyse préliminaire pour notre étude de l'évidentialité en anglais. Des exemples authentiques issus du corpus nous permettent d'illustrer et de compléter les descriptions du groupe verbal tibétain dans plusieurs travaux pionniers antérieurs à la présente recherche (Tournadre 1996; Tournadre \& 
Sangda Dorje 1998; Vokurková 2008; Oisel 2013) afin de poser les bases de la sémantique évidentielle.

3 Les marqueurs évidentiels qui émergent dans les parties tibétaine et anglaise du corpus sont examinés afin de déterminer les paramètres qui motivent leur utilisation. Les marqueurs tibétains sont principalement grammaticaux et intégrés à des paradigmes syntaxiques : copules ('dug), suffixes verbaux (-song, -gi.'dug, -bzhag) et enclitiques (-za et -ze). Les marqueurs évidentiels anglais sont lexicaux ou semi-grammaticaux : verbes de perception, verbes de cognition, verbes de discours, modaux, adverbes, conjoints, parenthétiques et marqueurs de discours (Nuyts 2001, Cappelli 2007, Sanders \& Sweetser 2009, Mortensen 2010, Whitt 2010, Gisborne 2010, Miller 2008, Boulonnais 2010, Gurajek 2010, Kaltenböck et al. 2011, Heine 2013).

Cette description de l'évidentialité en tibétain et en anglais nous permet d'analyser les conséquences d'un rendu grammatical ou lexical de cette notion (Talmy 2000, Bybee et al. 1994, Nuyts 2001, Boye \& Harder 2009). Les analyses contrastives sur les corpus recueillis et sur large corpus illustrent les différences de complexité, d'optionalité, de fréquence, de restriction sémantique, de prise en charge, de statut informatif et de stratégie de discours dans les deux systèmes. Le premier point qu'il convient de noter est que le système tibétain est plus unifié, puisque l'évidentialité s'y exprime le plus souvent par des suffixes verbaux et des copules, alors que l'évidentialité anglaise émerge dans une dizaine de catégories syntaxiques. Ensuite, l'évidentialité en anglais est plus complexe, dans le sens où son expression demande généralement plus d'éléments morphologiques, phonologiques et syntaxiques. Par exemple, le tibétain standard peut exprimer en une syllabe une information obtenue de quelqu'un qui a été un témoin direct de l'événement: -song-ze (prononcé /sõys/). En revanche, cette distinction évidentielle se rendra en anglais par une formule comme 'I heard from someone who was there that...' Ensuite, le système anglais est plus optionnel, bien que la présence de marqueurs factuels en tibétain dans le même paradigme syntaxique rende l'ensemble du système semi-obligatoire, du moins d'un point de vue sémantique. Par ailleurs, les données quantitatives des deux corpus indiquent que l'évidentialité est encodée six fois plus souvent en tibétain qu'en anglais. La sémantique lexicale est typiquement plus spécifique que la sémantique grammaticale. Par exemple, les enclitiques de ouï-dire -za et -ze couvrent tout le spectre de l'évidentialité par ouï-dire, tandis que les équivalents anglais comportent davantage de traits sémantiques. Enfin, pour plusieurs raisons linguistiques et cognitives, l'évidentialité grammaticale se situe davantage à l'arrière-plan que l'évidentialité lexicale.

5 Cette étude réévalue la dichotomie, souvent considérée comme acquise, entre évidentialité grammaticale et lexicale (Aikhenvald 2004). Nous avançons que les marqueurs évidentiels des deux langues se positionnent à différents endroits sur un continuum multidimensionnel lexique-grammaire. Il n'est pas remis en question que le système évidentiel tibétain est plus grammaticalisé que le système anglais, mais on démontre que ce dernier présente tous les signes d'une grammaticalisation partielle: évolution sémantique vers l'abstrait, réduction, décatégorisation, etc. Par exemple, une expression comme ØSounds like marque le passage d'un verbe d'émission sonore à un marqueur inférentiel à partir de sources verbales (auditives ou écrites) : 'Sounds like he's having serious problems, doesn't he?' Il s'agit par ailleurs d'une anomalie syntaxique, puisque non seulement l'anglais autorise ici l'effacement du pronom sujet, mais l'exploite dans une perspective de spécialisation sémantique: ØSounds like peut 
seulement marquer l'inférence, et ne plus encoder la simple apparence, contrairement à It sounds like : 'It sounds like he's having serious problems, but actually he is fine.' Il s'agit simplement d'un exemple parmi d'autres de la grammaticalisation de l'évidentialité en anglais, ce qui amène à conclure que l'évidentialité doit être intégrée à la recherche en anglais pour une description précise et complète de cette langue.

\section{Evidentiality in English : a contrastive study on a Tibetan-English corpus}

6 This thesis gives a detailed description of evidentiality in English in contrast with Tibetan. Evidentiality is presented as a universal semantic domain expressing the mode of access to the asserted information. This study is based on specialised corpora collected in Tibet and in England (TSC and CSC/LAC, 2010-2012, $10 \mathrm{~h}$.). These corpora were designed to elicit numerous evidentials by asking questions related to diverse modes of access to information. Using the same methodology for both English and Tibetan enabled us to gather comparable data both quantitatively and qualitatively.

7 Tibetan has a complex and grammaticalised evidential system, and its description can provide a preliminary analytical grid for a semantic assessment of English evidentiality. Authentic examples from the corpora illustrate and supplement the analyses of the Tibetan verb phrase from previous research (Tournadre 1996; Tournadre \& Sangda Dorje 1998; Vokurková 2008; Oisel 2013), in order to lay the foundation of the semantics of evidentiality.

8 The evidential markers that emerge in the Tibetan and English sections of the corpora are examined so as to determine the parameters that motivate their usage. Tibetan evidentials are mainly grammatical and paradigmatised : copulas ('dug), verb suffixes (gi.'dug, -song, -bzhag) and enclitics (-za and -ze). English evidentials are either lexical or semi-grammatical : perception verbs, cognition verbs, speech verbs, modals, adverbs, conjuncts, parentheticals and discourse markers (Nuyts 2001a, Cappelli 2007, Sanders \& Sweetser 2009, Mortensen 2010, Whitt 2010, Gisborne 2010, Miller 2008, Boulonnais 2010, Gurajek 2010, Kaltenböck et al. 2011, Heine 2013).

9 This survey of Tibetan and English evidentiality provides precise data for the analysis of the consequences of a grammatical or a lexical rendering of the notion (Talmy 2000, Bybee et al. 1994, Nuyts 2001a, Boye \& Harder 2009). Linguistic evidence illustrates the differences in complexity, optionality, frequency, semantic restriction, speaker commitment, informative status and discourse strategy in the two systems. The Tibetan system is more homogeneous because Tibetan evidentials are mainly verb suffixes, copulas and enclitics, whereas in English evidentiality emerges in about ten syntactic categories. English evidentiality is more complex in the sense that it usually requires more morphological, phonological and syntactic elements. For example, Tibetan speakers can express in one syllable that the asserted information comes from what a direct witness said:-song-ze. In English however, only a longer phrase can render this evidential meaning: I heard from someone who was there that... The quantitative data from the contrastive corpus also indicates that Tibetan expresses evidentiality six times more frequently than English. Furthermore, lexical semantics is typically more specific than grammatical semantics. For example, the Tibetan enclitics $-z a$ and $-z e$ cover the whole spectrum of hearsay evidentiality, whereas their English 
equivalents (He said, I was told, I heard, apparently...) contain more semantic features. Finally grammatical evidentiality is more backgrounded than lexical evidentiality in terms of information hierarchy for several linguistic and cognitive reasons.

This study reassesses the assumed dichotomy between grammatical and lexical evidentiality (Aikhenvald 2004), arguing that evidentials in both Tibetan and English inhabit a lexicon-grammar multidimensional continuum where they merely occupy different positions. This study does not question that the Tibetan evidential system is more grammaticalised than the English one, but it shows that the latter presents all the signs of partial grammaticalisation: semantic evolution, reduction, decategorisation, etc. For example, a conventionalised phrase such as ØSounds like shows the evolution of a verb of acoustic emission to an inferential marker from verbal sources (auditory or written) : 'Sounds like he's having serious problems, doesn't he?' This marker presents a syntactic anomaly, because not only English allows the omission of the subject pronoun here, but exploits it for the sake of semantic specialisation. ØSounds like can only encode inference and not mere appearance, unlike It sounds like: 'It sounds like he's having serious problem, but actually he's fine.' The evolution of sound is just one example of the grammaticalisation of English evidentiality, and this notion is therefore perfectly relevant and necessary for a thorough and accurate description of English.

\section{BIBLIOGRAPHIE}

Aijmer, K.

1997 I think-an English modal particle1, Modality in Germanic languages : Historical and comparative perspectives, 99, 1.

2009 Seem and evidentiality, Functions of language, 16, 1, pp. 63-88.

Aikhenvald, A. Y.

2004 Evidentiality (Oxford University Press).

Anscombre J.-C.

2014 Introduction, in J-Cl. Anscombre, E. Oppermann-Marsaux, A. Rodriguez Somolinos (éds.), Médiativité, polyphonie et modalité en français : études synchroniques et diachroniques (Presses Sorbonne Nouvelle).

Bednarek, M.

2006 Epistemological positioning and evidentiality in English news discourse : A text-driven approach, Text \& Talk-An Interdisciplinary Journal of Language, Discourse Communication Studies, 26, 6, pp. 635-660.

Boulonnais, D.

2010 Verbes de perception et mode de complémentation verbale, in Khalifa J-C. et Miller P. (eds.), Perception et structure linguistiques. Huit études sur l'anglais, Presses Universitaires de Rennes.

Boye, K. \& Harder, P.

2009 Evidentiality : Linguistic categories and grammaticalization, Functions of Language, 16, 1), pp. 9-43. 
Bres, J. (ed.)

2005 Dialogisme et polyphonie : approches linguistiques. De Boeck Supérieur.

Bybee, J., Perkins, R., \& W. Pagliuca

1994 The evolution of grammar : Tense, aspect, and modality in the languages of the world (University of Chicago Press).

Cappelli, G.

2007 'I Reckon I Know how Leonardo Da Vinci Must Have Felt', Epistemicity, Evidentiality and English Verbs of Cognitive Attitude (USA, Pari Publishing).

Chafe, W. L., \& J. Nichols

1986 Evidentiality : The linguistic coding of epistemology.

Cornillie, B.

2007 The continuum between lexical and grammatical evidentiality : a functional analysis of Spanish parecer, Italian Journal of Linguistics, 19, pp. 109-128.

De Haan, F.

1999 Evidentiality and epistemic modality : Setting boundaries, Southwest journal of linguistics, 18, 1 , pp 83-101.

Dehe, N., \& A. Wichmann

2010 Sentence-initial I think (that) and I believe (that) : Prosodic evidence for use as main clause, comment clause and discourse marker, Studies in Language, 34, 1, pp. 36-74.

DeLancey, S.

1985 / 2011, Lhasa Tibetan evidentials and the semantics of causation, In Proceedings of the Annual Meeting of the Berkeley Linguistics Society (Vol. 11).

1986 Evidentiality and volitionality in Tibetan, Chafe \& Nichols (eds.), pp. 203-213.

Denison, D.

1992 The information present : present tense for communication in the past. History of Englishes. New Methods and Interpretations in Historical Linguistics, pp. 262-286.

Diewald, G., \& E. Smirnova (eds.)

2010 Linguistic realization of evidentiality in European languages (Vol. 49), Walter de Gruyter.

Garrett, E. J.

2001 Evidentiality and assertion in Tibetan (Doctoral dissertation, University of California, Los Angeles).

Gisborne, N.

2010 The event structure of perception verbs (Oxford University Press).

Gurajek, B.

2010 Evidentiality in English and Polish (Doctoral dissertation).

Guentchéva, Z.

1994 Manifestations de la catégorie du médiatif dans les temps du français. Langue française, pp. 8-23.

1995 L'énonciation médiatisée et les mécanismes perceptifs. Langue et langage, Problèmes et raisonnement en linguistique. Mélanges offerts à Antoine Culioli (Paris, PUF), pp. 301-315.

Heine, B.

2013 On discourse markers : Grammaticalization, pragmaticalization, or something else ?.

Linguistics, 51, 6, pp. 1205-1247. 
Hopper, P. J., \& E. C. Traugott

1993 Grammaticalization. Cambridge textbooks in linguistics (Cambridge, CUP).

Kaltenböck, G., Heine, B., \& T. Kuteva

2011 On thetical grammar, Studies in language, 35, 4, pp. 852-897.

Kärkkäinen, E.

2003 Epistemic stance in English conversation : A description of its interactional functions, with a focus on I think (John Benjamins Publishing).

Lazard, G.

2001 On the grammaticalization of evidentiality, Journal of Pragmatics, 33, 3, pp. 359-367.

Matlock, T.

2011 Metaphor and the Grammaticalization of Evidentials, in Proceedings of the Annual Meeting of the Berkeley Linguistics Society (Vol. 15).

Miller, P.

2008 Prédication et évidentialité : de l'emploi copule des verbes de perception en anglais, Faits de langues, 31-32.

Mortensen, J.

2010 Epistemic and Evidential Sentence Adverbials in Danish and English (Doctoral dissertation, A).

Newmeyer, F. J.

2000 Deconstructing grammaticalization, Language sciences, 23, 2, p. 187.

Nuyts, J.

2001 Epistemic modality, language, and conceptualization : A cognitive-pragmatic perspective (Vol. 5)

(John Benjamins Publishing).

Oisel, G.

2013 Morphosyntaxe et sémantique des auxiliaires et des connecteurs du tibétain littéraire :

étude diachronique et synchronique (Doctoral dissertation, Université de la Sorbonne nouvelleParis 3).

Sanders, T., \& Sweetser, E. (eds.)

2009 Causal categories in discourse and cognition (Vol. 44). Walter de Gruyter.

Talmy, L.

2000 Toward a cognitive semantics, vol. 1 : Concept structuring systems (The MIT Press).

Thompson, S. A., \& A. Mulac

1991 A quantitative perspective on the grammaticization of epistemic parentheticals in English, Approaches to grammaticalization, 2, pp. 313-329.

Tournadre, N. \& Sangda Dorje

1998 Manuel de tibétain standard (L'Asiathèque).

1996 L'ergativité en tibétain. Approche morphosyntaxique de la langue (Paris, Éditions Peeters Louvain).

Vokurková, Z.

2008 Epistemic modalities in spoken standard Tibetan (Doctoral dissertation, Thèse de doctorat. Filozoficka Fakulta Univerzity Karlovy-Université Paris 8).

Whitt, R. J.

2010 Evidentiality and perception verbs in English and German (Vol. 26) (Peter Lang). 